$\mathrm{DOI}$

\title{
ОБҐРУНТУВАННЯ МЕХАНІЗМУ ДІї НАНООКСИДІВ МЕТАЛІВ НА ПАТОГЕННУ ФЛОРУ ГНІЙНИХ РАН
}

\author{
๑о. я. Попадюк, Д. О. Мельник \\ ДВНЗ «Івано-Франківський національний медичний університет»
}

РЕЗЮМЕ. Проблема лікування гнійних ран залишається актуальною до теперішнього часу. Неправильне застосування антибіотиків та неефективне лікування змушує проводити пошук, вивчення та впровадження нових протимікробних засобів боротьби з інфекцією у рані. На сьогодні все частіше з'являються повідомлення про високу антибактеріальну ефективність нанорозмірних оксидів металів. На жаль, не до кінця зрозумілим $\epsilon$ механізм дії нанооксиду цинку на бактеріальну клітину. Метою нашої роботи було обґрунтування дії нанооксиду цинку на бактерію за допомогою квантово-хімічних розрахунків. Для проведення розрахунків структурних та енергетичнихпараметрів досліджуваних систем застосували напівемпіричний метод РМЗ. В результаті проведених квантохімічних розрахунків обґрунтовано антибактеріальну дію нанооксидів, зокрема нанооксиду цину, де енергетично вигідне відщеплення радикалу кисню від поверхні нанооксиду цинку приводить до проведення низки радикальних реакцій з утворенням пероксидів та подальшим руйнуванням бактерій.

КЛЮЧОВІ СЛОВА: нанооксиди, нанооксид цинку, нанооксид магнію, патогенна флора, механізм дії, квантовохімічні розрахунки.

Вступ. Незважаючи на постійний пошук нових медикаментозних засобів для місцевого і загального лікування хірургічної інфекції, проблема лікування гнійних ран залишається актуальною до теперішнього часу. Найбільші труднощі хірург відчуває при лікуванні інфікованих ран. Частота хірургічних інфекцій у структурі хірургічних захворювань в останні роки не знижується, залишаючись на рівні 24-36 \%. Неадекватне ведення пацієнтів з хірургічною інфекцією $є$ однією з причин високої летальності в цій популяції пацієнтів $25-50 \%[1,2]$.

У комплексному лікуванні гнійно-запальних процесів найважливішою складовою $\epsilon$ місцева антисептика. Це обумовлено тим, що системне застосування потужних протимікробних препаратів, а саме антибіотиків, не завжди досягає мети, оскільки у відмежованому запальним валом вогнищі інфекції не створюється необхідна концентрація засобу [3].

Удосконалення місцевого лікування ран спрямоване, перш за все, на застосування сучасних високоефективних препаратів залежно від конкретної фази ранового процесу [4].

На сьогодні у сучасній медицині як протимікробні лікарські засоби застосовують наночастинки оксидів срібла, міді, заліза, цинку, магнію та інших металів [5].

Одним з таких елементів $\epsilon$ нанооксид магнію, який має властивість адсорбувати і утримувати протягом тривалого часу на своїй поверхні (в порядку місяців) значну кількість елементарного хлору і брому [6]. Ці наночастинки мають певну протимікробну активність щодо деяких вегетативних грампозитивних бактерій, грамнегативних бактерій і спор [7].
Стандартні бактеріологічні дослідження показали високу активність проти E. coli i Bacillus megaterium i хорошу активність проти спор Bacillus subtilis [8]. Біоактивність наночастинок оксиду магнію пов'язана з позитивним зарядом, що вони мають у водній суспензії, протилежні тим, які мають бактерії і спори, що підвищує загальний бактерицидний ефект. В цілому, галогени, такі як хлор і бром на поверхні наночастинок MgO підсилюють ефективність і швидкість бактерицидної дії на грампозитивні та грамнегативні бактерії і спори [8].

Наведені у науковій літературі результати експериментальних досліджень показують, що дія оксиду цинку на штами патогенних мікроорганізмів зростає зі зменшенням розміру його частинок [9].

Результати дослідження, отримані на піддослідних тваринах, показали, що пов'язки з нанооксидом цинку підсилюють загоєння опікових ран, хронічних ран, виразок діабетичної стопи і сприяють більш швидкій реепітелізації рани і відкладенню у ній колагену. Отримані дані переконливо заохочують до використання цих композитних бандажів [10].

Описані в літературі експериментальні дослідження підтверджують антисептичні властивості нанооксиду цинку, та автори припускають, що антибактеріальний механізмом його дії, швидше за все, обумовлений порушенням клітинної мембрани і виникненням окисного стресу в патогенній бактерії [11].

Зустрічаються також інші припущення, що, можливо, саме фотокаталітичне утворення перекису водню $є$ одним з основних механізмів антимікробної дії. Також на гальмування росту мікро- 
Огляди літератури, оригінальні дослідження, погляд на проблему

організмів впливає проникнення наночастинок у бактеріальну мембрану та подальше її руйнування при контакті з наночастинками оксиду цинку. Було висловлено припущення, що $\mathrm{Zn}^{2+}$-йонне зв'язування з мембранами мікроорганізмів може продовжити фази циклу мікробного росту $[9,12]$.

Особливу увагу було приділено припущенню щодо бактерицидних і бактеріостатичних механізмів нанооксиду цинку з акцентом на генерацію активних форм кисню, включаючи перекис водню $\left(\mathrm{H}_{2} \mathrm{O}_{2}\right), \mathrm{OH}$ (гідроксильних радикалів) і О (радикал кисню). Генерація активних форм кисню була одним з основних факторів протягом декількох механізмів, включаючи пошкодження стінки бактерії внаслідок локальної взаємодії з нанооксидом цинку, підвищенням проникності мембран, інтерналізації NPs у зв'язку з втратою протонів рушійної сили і поглинання розчинених токсичних йонів цинку [13].

Наявність таких припущень щодо протимікро6ної дії нанооксидів у вигляді різних розмірів привело до пошуку пояснення цього явища із врахуванням хімічної будови. Для цього можна застосувати квантово-хімічні розрахунки геометричної та електронної будови досліджуваних об'єктів [14].

Одним $з$ таких методів розрахунку структурних та енергетичних параметрів досліджуваних систем $\epsilon$ напівемпіричний метод РМЗ. Такий метод комп'ютерного моделювання дозволяє отримувати детальну та повну інформацію на мікрорівні щодо досліджуваних об'єктів у рамках адекватних моделей при мінімальних затратах машинного ресурсу, аналіз якої дає змогу оцінити макроскопічні параметри, які отримують у відповідних дослідах [15].

Мета дослідження: обгрунтувати механізм антимікробної дії нанооксидів металів за допомогою квантово-хімічних розрахунків.

$$
\begin{aligned}
& \mathrm{Zn}_{\mathrm{n}} \mathrm{O}_{\mathrm{n}} \longrightarrow \cdot \mathrm{Zn}_{\mathrm{n}} \mathrm{O}_{\mathrm{n}-1}+\cdot \mathrm{O} \cdot \\
& \mathrm{Mg}_{\mathrm{n}} \mathrm{O}_{\mathrm{n}} \longrightarrow \cdot \mathrm{Mg}_{\mathrm{n}} \mathrm{O}_{\mathrm{n}-1}+\cdot \mathrm{O} \cdot \\
& \mathrm{Zn}_{\mathrm{n}} \mathrm{O}_{\mathrm{n}} \longrightarrow \cdot \mathrm{Zn}_{\mathrm{n}-1} \mathrm{O}_{\mathrm{n}}+\cdot \mathrm{Zn} \cdot \\
& \mathrm{Mg}_{\mathrm{n}} \mathrm{O}_{\mathrm{n}} \longrightarrow \cdot \mathrm{Mg}_{\mathrm{n}-1} \mathrm{O}_{\mathrm{n}}+\cdot \mathrm{Mg} \cdot
\end{aligned}
$$

Тверді частинки мають свою певну кристалічну структуру: цинк оксид - гексагональна сингонія, магній оксид - кубічна сингонія, відповідно атоми, що розташовуються на поверхні, можуть перебувати або на кутах граней, або на ребрах, або на площині грані. Розташування атомів може впливати на їх здатність до дисоціації. Здатність до дисоціації можна визначити за зниженням
Матеріал і методи дослідження. Ми провели квантово-хімічне вивчення нанооксидів цинку та магнію.

Високодисперсні оксиди металів, а саме їх наночастинки, мають дуже малі розміри, великі площі поверхонь і незвичайну кристалічну морфологію - численні грані, кути і реакційно здатні ділянки поверхонь [16].

Оксид магнію (MgO) має наночастинки квадратної та багатогранної форм з різними діаметрами близько 4 нм з велкою кількістю пор [17].

Кристал нанооксиду цинку - шестикутний вюрцит, має часткові полярні характеристики та добрі антисептичні властивості [18].

Квантово-хімічні дослідження проводили за допомогою програми НурегChem 8.0.9 for Windows на комп'ютері 3 тактовою частотою 3.0 ГГц. оперативною пам'яттю 4 Гб. Оптмізацію геометрії та структури всіх речовин проводили методом РМ3, оскільки більш точні методи для об'єктів, що нараховують велике число атомів, застосувати на звичайному комп'ютері практично неможливо.

Метод РМЗ $є$ версією відомого методу АМ1. РМ3 відрізняється від АМ1 тільки величинами параметрів. Параметри для РМЗ були отримані порівнянням великого числа і виду експериментів з результатами розрахунків. РМЗ спочатку призначався для розрахунків органічних молекул, але потім він був також параметризований і для ряду інших груп елементів, зокрема для перехідних металів. Тому і був обраний для дослідження структур оксидів металів [19].

Результати й обговорення. Дослідження процесів гомолітичної або гетеролітичної дисоціації на поверхні кристалів оксидів цинку та мангану можна представити наступними схемами:

$$
\begin{aligned}
& \mathrm{Zn}_{\mathrm{n}} \mathrm{O}_{\mathrm{n}} \longrightarrow \mathrm{Zn}_{\mathrm{n}} \mathrm{O}_{\mathrm{n}-1}{ }^{2+}+\mathrm{O}^{2-} \\
& \mathrm{Mg}_{\mathrm{n}} \mathrm{O}_{\mathrm{n}} \longrightarrow \mathrm{Mg}_{\mathrm{n}} \mathrm{O}_{\mathrm{n}-1}{ }^{2+}+\mathrm{O}^{2-} \\
& \mathrm{Zn}_{\mathrm{n}} \mathrm{O}_{\mathrm{n}} \longrightarrow \mathrm{Zn}_{\mathrm{n}-1} \mathrm{O}_{\mathrm{n}}{ }^{2-}+\mathrm{Zn}^{2+} \\
& \mathrm{Mg}_{\mathrm{n}} \mathrm{O}_{\mathrm{n}} \longrightarrow \mathrm{Mg}_{\mathrm{n}-1} \mathrm{O}_{\mathrm{n}}{ }^{2-}+\mathrm{Mg}^{2+}
\end{aligned}
$$

загальної енергії системи після дисоціації ( $\Delta \mathrm{E}=$ $\mathrm{E}_{\text {прод. }}-\mathrm{E}_{\text {вих. }}$ ). Дані квантово-хімічного моделювання таких систем наведені в таблиці 1.

Зниження енергій системи спостерігається лише при утворенні радикалів оксигену на поверхні цинк оксиду, що може провокувати цілий ряд вільнорадикальних перетворень, найпростіший варіант: 
Огляди літератури, оригінальні дослідження, погляд на проблему

$$
\begin{gathered}
\cdot \mathrm{O} \cdot+\mathrm{H}_{2} \mathrm{O} \longrightarrow \cdot \mathrm{OH}+\cdot \mathrm{OH} \\
\cdot \mathrm{OH}+\cdot \mathrm{OH} \longrightarrow \mathrm{H}_{2} \mathrm{O}_{2}
\end{gathered}
$$

Таблиця 1. Зміна енергії системи $(\Delta \mathrm{E})$ процесів дисоціації (1-8) розрахована напівемпіричним методом РМ3.

\begin{tabular}{|c|c|c|c|c|}
\hline \multirow{2}{*}{ Номер процесу } & \multicolumn{3}{|l|}{ Зміна енергії системи (кДж/моль) при дисоціації атома чи йона, що знаходиться в кристалі } \\
\cline { 2 - 5 } & у куті & на ре6рі & -153 & на грані \\
\hline$(1)$ & -61 & -141 & 2582 & 263 \\
\hline$(2)$ & 2778 & 2674 & 677 & 706 \\
\hline$(3)$ & 731 & 485 & 2876 & 2950 \\
\hline$(4)$ & 2989 & 2684 & 1523 & 1618 \\
\hline$(5)$ & 968 & 1522 & 2659 & 2723 \\
\hline$(6)$ & 2475 & 2655 & 774 & 744 \\
\hline$(7)$ & 916 & 607 & 2659 & 2696 \\
\hline$(8)$ & 2843 & 2673 & \\
\hline
\end{tabular}

Кисневі радикали: $\mathrm{O}_{2}^{-}-$супероксидний; ОН гідроксильний; $\mathrm{O}_{2} \mathrm{H}$ - пероксидний мають високу реакційну здатність і взаємодіють з багатьма речовинами організмів, у тому числі - нуклеїновими кислотами, білками, ліпідами та іншими сполуками, викликаючи порушення їхніх функцій.

Моделювання структури нанооб'єктів, які зазвичай мають десятки та сотні нанометрів, які включають кілька сотень або тисяч атомів, за допомогою точних квантово-хімічних Abinitio та DFT, і навіть більш наближених напівемпіричних методів $\epsilon$ неможливим на сучасних персональних комп'ютерах. Для таких об'єктів є можливість застосування лише методів молекулярної механіки, які $\epsilon$ дуже неточними та не приймають до уваги взаємодію молекулярних орбіталей. Модель кристала гексагональної сингонії оксиду цинку, створена методом молекулярної механіки, при моделюванні напівемпіричним методом РМ3 [19] дещо змінює розташування атомів в кристалі, при якому поверхневі атоми Оксигену дещо віддаляються від кристалу, і навпаки, атоми цинку зміщуються дещо досередини (рис. 1). Таким чином виходить частинка, на поверхні якої зосереджуються в основному атоми оксигену. Більш рухомі поверхневі атоми оксигену можуть відриватись або гомолітично, або гетеролітично. При гетеролітичному розриві, в залежності від розташування атома на поверхні, енергія системи зростає на 2500-2700 кДж/моль, і навпаки, зменшується при гомолітичному розриві на 60-150 кДж/моль. При відриванні від кристалу радикала чи йона цинку енергія системи зростає відповідно на 1000-1500 кДж/моль та 2700-2900 кДж/моль. Отже, найбільш енергетично вигідним $\epsilon$ процес відщеплення від поверхні кисневих радикалів, які можуть в подальшому утворювати цілий ряд інших радикалів, що і спричиняє їх антимікробну дію. Чим менший розмір частинок, тим їх поверхня більша, а отже більше число активних атомів оксигену.

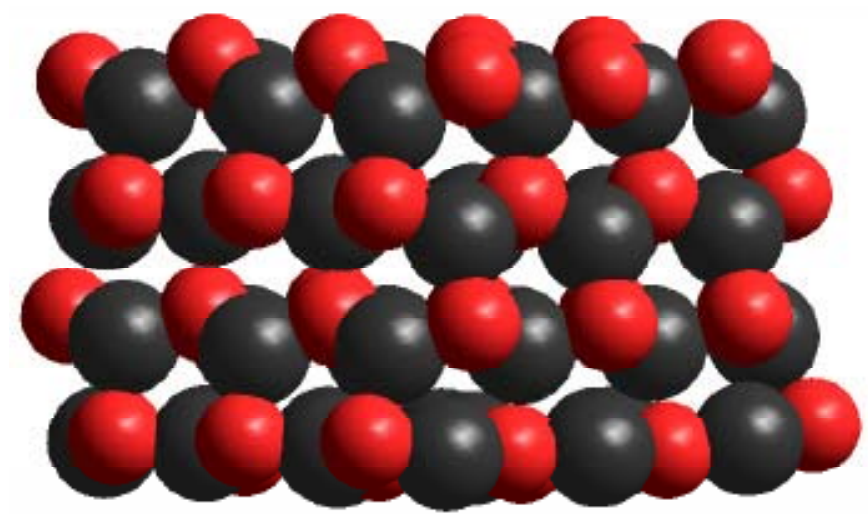

Рис.1. Структура невеликого (60 молекул, 1,7 нм) кристалу ZnO, змодельована напівемпіричним методом РM3.

Проте зменшення до молекулярного розміру не завжди буде дієвим. Наночастинки оксиду цинку проявляють напівпровідникові властивості, i, як відомо з експериментальних досліджень
[18], енергетична щілина (різниця енергій між В3МО і НВМО) у них складає 3,3 еВ (рис. 2). Як видно з розрахунків методом РМ3, у маленького кристала, який складається з шести молекул окси- 
Огляди літератури, оригінальні дослідження, погляд на проблему

ду цинку (частинка розміром приблизно 0,4 нм) енергетична щілина складає 8,43 еВ. При збільшенні кристалу відбувається спряження більшої кількості орбіталей, що призводить до взаємодії між енергетичними рівнями і їх розчеплення. Відбувається зменшення енергетичної щілини i наближення до якогось сталого значення. При збільшенні кристалу оксиду цинку до 38 молекул (частинка розміром приблизно 1 нм) енергетична щілина складає 4,85 еВ, що наближається до експериментальних значень.

При моделюванні структури магнію оксиду поверхневі атоми оксигену не віддаляються від поверхні, і дисоціація, як радикальна, так і гетеролітична, в магнію оксиді енергетично не вигідна, тому малоймовірна (рис. 3) Оскільки не будуть утворюватись радикали, то магнію оксид не буде проявляти антибактеріальної дії.

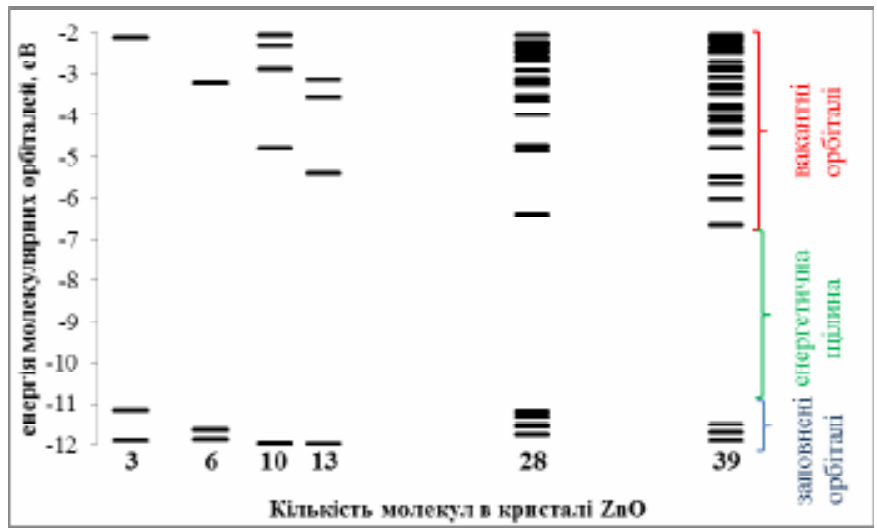

Рис. 2. Зменшення енергетичної щілини в кристалі ZnO, розраховане методом PM3.

Результати й обговорення. Вивчаючи антибактеріальну активність суспензії наночастинок оксиду цинку розміром 30 нм стосовно широкого спектра мікроорганізмів було встановлено відсутність значного гальмування росту мікроорганізмів при використанні $\mathrm{MgO}, \mathrm{TiO}_{2}, \mathrm{CuO}$ та $\mathrm{CeO}_{2}$, але значне гальмування росту при використанні $\mathrm{Al}_{2} \mathrm{O}_{3}$ (близько 50 \%) і ZnO ( $\geq 50 \%)$. Для ультрадисперсних порошків ZnO і нанопорошків ZnO зниження темпів росту (близько $50 \%$ ) не виявлено. Однак наночастинкам ZnO з меншим розміром вдалося зменшити ріст колонії майже на 99 \% [20].

Саме такі дані підтверджують отримані нами результати квантово-хімічних розрахунків, де обґрунтовано механізм високої антимікробної властивості нанооксидів металів, зокрема нанооксиду цинку, завдяки особливій структурі та можливості формування кисневих радикалів, які можуть в подальшому утворювати цілий ряд інших радикалів, що мають високу антимікробну дію.

Висновки. 1. Завдяки проведенню квантовохімічних розрахунків структурнихта енергетичних характеристик оксидів металів напівемпіричним

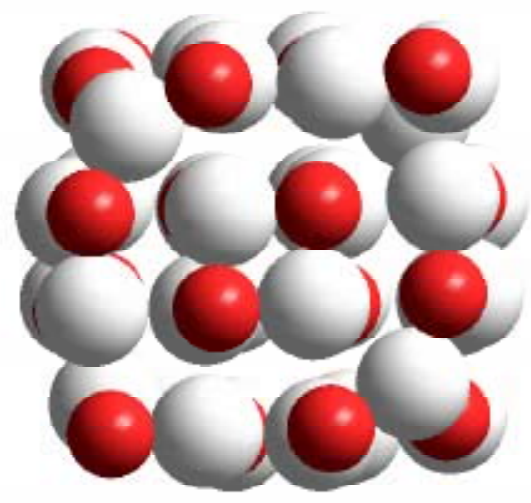

Рис. 3. Структура невеликого (32 молекули, 1,01 нм) кристалу MgO змодельована напівемпіричним методом РМЗ.

методом обґрунтовано механізм антисептичної дії їх нанорозмірних часток, зокрема нанооксиду цинку.

2. Розуміння механізму дії нових високоефективних дрібнодисперсних протимікробних засобів місцевої дії дозволить ефективно боротись 3 патологічними бактеріями у ранах різного генезу, зменшити кількість ускладнень та покращити якість лікування хірургічних хворих.

3. Впровадження у хірургічну практику нових нанорозмірних засобів боротьби з патогенними мікроорганізмами при лікуванні гнійних ран потребує подальшого всебічного їх експериментального та клінічного вивчення.

Перспективи подальших досліджень. Дослідження структурних та енергетичних характеристик дрібнодисперсних нанооксидів металів та вивчення можливості їх взаємодії з патогенними мікроорганізмами гнійних ран $\epsilon$ на сьогодні надзвичайно перспективним та вагомим для подальших наукових досліджень механізмів протимікробної активності нанорозмірних металів та їх оксидів. 


\section{ЛІТЕРАТУРА}

1. Горюнов С. В. Гнойная хирургия. Атлас / С. В. Горюнов, Д. В. Роашов, И. А. Бутивщенко. - М. : Бином. 2004. -558 C.

2. The epidemiology of hospitalized cases of skin and soft tissue infection in Europe / S. Pulgar, M. Mehra, A. Quintara [et al.] // Abstr 18th ECCMID. - Barselona, Spain. - 2008. - P. 821.

3. Палій Г. К. Порівняльна характеристика антисептичної ефективності декаметоксину та фурациліну / Г.К. Палій, М. Є. Нечитайло, В. П. Ковальчук [et al.] // Здоров'я України. - 2010. - № 22. - С. 56-57.

4. Блаутин Л. А. Местное медикаментозное лечение ран. Проблемы и новые возможности их решения / Л. А. Блаутин // Consilium medicum: хирургия (прилож). 2007. - № 1. - С. 9-16.

5. Чекман І. С. Нанонаука: історичний аспект, перспективи досліджень / І. С. Чекман // Укр. Мед. Часопис. - 2009. - № 3 (71), T. V/VI. - C. 19-21.

6. Huang L. Controllable preparation of Nano-MgO and investigation of its bactericidal properties / L. Huang // J. Inorg Biochem. - 2005. - Vol. 99. - P. 986-993.

7. Consolidation of Metal Oxide Nanocrystals. Reactive Pellets with Controllable Pore Structure That Represent a New Family of Porous, Inorganic Materials / R. Richards, W. Li, S. Decker [et al.] // J. Am. Chem. Soc. - 2000. Vol. 122. - P. 4921-4925.

8. Nanoscale Powders and Formulations with Biocidal Activity Toward Spores and Vegetative Cells of Bacillus Species, Viruses, and Toxins / O. Koper, J. Klabunde, G. Marchin [et al.] // Current Microbiology. - 2002. Vol. 44. - P. 49-55.

9. Padmavathy N. Enhanced bioactivity of ZnO nanoparticles-an antimicrobial study / N. Padmavathy, R. Vijayaraghavan // Sci. Technol. Adv. Mater. - 2008. - Vol. 9. - P. 1-7.

10. Flexible and Microporous Chitosan Hydrogel / Nano ZnO Composite Bandages for Wound Dressing: In Vitro and In Vivo Evaluation / P. T. Sudheesh Kumar, VinothKumar Lakshmanan, T. V. Anilkumar [et al.] // ACS Appl.
Mater. Interfaces. - 2012. - Vol. 4 (5). - P. 2618-2629.

11. Antibacterial Activity and Mechanism of Action of Zinc Oxide Nanoparticles against Campylobacter jejuni // Y. Xie, Y. He, P. L. Irwin [et al.] // Applied and Environmental Microbiology. - 2011. - Vol. 4. - P. 2325-2331.

12. Цинк і наноцинк: властивості, застосування у клінічній практиці // І. С. Чекман, 3. Р. Ульберг, А. Д. Руденко [та ін.] // Укр. Мед. Часопис. - 2013. - № 2 (94), T. III/IV. - C. 42-47.

13. Review on Zinc Oxide Nanoparticles: Antibacterial Activity and Toxicity Mechanism/A. Sirelkhatim, S. Mahmud A. Seeni [et al.] // Nano-Micro Lett. - 2015. - Vol. 7 (3). P. 219-242.

14. Броварець О. О. Квантово-хімічне дослідження елементарнихмолекулярних механізмів піримідиновопуринових трансверсій / О. О. Броварець Д. М. Говорун // Укр. біохім. журн. - 2010. - № 5, Т. 8. - С. 257-267.

15. Квантово-хімічне моделювання взаємодії метилтретбутилового ефіру з ліпідним шаром плазматичної мембрани / О. П. Яворовський, В. В. Лобанов, О. Г. Мінченко [та ін.] // Український медичний журнал 3 проблем медицини праці. - 2015. - № 2 (43). - С. 32-40.

16. Stoimenov P. K. Metal oxide nanoparticles as bactericidal agents / P. K. Stoimenov // Langmuir. - 2002. Vol. 18. - P. 6679-6686.

17. Klabunde KJ. Nanocrystals as Stoichiometric Reagents with Unique Surface Chemistry / K. J. Klabunde, J. Stark, O. Koper [et al.] // J. Phys. Chem. - 1996. Vol. 100. - P. 12142-12153.

18. Baruah S. Hydrothermal growth of $\mathrm{ZnO}$ nanostructures / S. Baruah, J. Dutta // Sci. Technol. Adv. Mater. 2009. - Vol. 10. - P. 1-18.

19. Соловев М. Е. Компьютерная химия / М. Е. Соловев, М. М. Соловев. - М. : СОЛОН-пресс, 2005. - 536 с.

20. Antibacterial activity of ZnO nanoparticle suspensions on a broad spectrum of microorganisms / N. Jones, B. Ray, K. T. Ranjit, A. C. Manna // FEMS Microbiol Lett. 2008. - Vol. 279 (1). - P. 71-76.

\section{JUSTIFICATION MECHANISM OF NANO METAL OXIDES ON PATHOGENIC FLORA PURULENT WOUNDS}

\section{Ivano-Frankivsk National Medical University}

SUMMARY. The problem of treatment of purulent wounds remains relevant to this day. Improper use of antibiotics and ineffective treatment leads to search, study and implementation of new antimicrobial drugs to combat infection in the wound. Today, there are increasing reports of high antibacterial effectiveness of nanoscale metal oxides, particularly zinc oxide. Unfortunately, we do not fully understand the mechanism of action of zinc nano oxides bacterial cell. The aim of our study was the action of nano zinc oxide in bacteria using quantum chemical calculations. Materials and methods. For the calculation used a PM3 method for calculating the structural and energy parameters of the systems. Result. As a result of quantum-chemical calculations proved antibacterial activity nano oxide zinc because the energetically beneficial radical removal of oxygen from the surface of the nano oxides leads to a series of radical reactions to form peroxides and subsequent destruction of bacteria.

KEY WORDS: nano oxide zinc, magnesium nano oxide, pathogenic flora, mechanism of action, quantum-chemical calculations.

Отримано 18.04.2016 